\title{
Allometric relationships between primary size measures and sapwood area for six common tree species in snow-dependent ecosystems in the Southwest United States
}

\author{
Bhaskar Mitra $^{1} \cdot$ Shirley A. Papuga ${ }^{1,2}$. \\ M. Ross Alexander ${ }^{1,3}$. Tyson Lee Swetnam ${ }^{4}$. \\ Nate Abramson ${ }^{5}$
}

Received: 24 December 2018 / Accepted: 19 June 2019 / Published online: 14 October 2019

(C) The Author(s) 2019

\begin{abstract}
High-elevation, snow-dependent, semiarid ecosystems across southwestern United States are expected to be vulnerable to climate change, including drought and fire, with implications for various aspects of the water cycle. To that end, much less is known about the dynamics of transpiration, an important component of the water cycle across this region. At the individual-tree scale, transpiration is estimated by scaling mean sap flux density by the hydroactive sapwood area (SA). SA also remains a key factor in effectively scaling individual tree water-use to stand level. SA across large spatial scales is normally established by relating SA of a few trees to primary size measures, e.g., diameter at breast height $(\mathrm{DBH})$, tree height $(H)$, or canopy
\end{abstract}

Project funding: The work was supported by the NSF National Critical Zone Observatories Program (EAR-0724958).

The online version is available at http://www.springerlink.com

Corresponding editor: Tao $\mathrm{Xu}$.

Electronic supplementary material The online version of this article (https://doi.org/10.1007/s11676-019-01048-y) contains supplementary material, which is available to authorized users.

Bhaskar Mitra

bhaskar.mitra6@gmail.com

1 School of Natural Resources and Environment, University of Arizona, Tucson, AZ 85721, USA

2 Department of Geology, Wayne State University, Detroit, MI 48202, USA

3 Laboratory of Tree-Ring Research, University of Arizona, Tucson, AZ 85721, USA

4 BIO5 Institute, University of Arizona, Tucson, AZ 85721, USA

5 Department of Hydrology and Water Resources, University of Arizona, Tucson, AZ 85721, USA diameter (CD). Considering the importance of SA in scaling transpiration, the primary objective of this study was therefore to establish six species-specific (aspen, maple, white fir, ponderosa pine, Douglas fir, Englemann spruce) allometric relationships between SA and three primary size measures (DBH, CD, or $H$ ) across two high-elevation, snow-dependent, semiarid ecosystems in New Mexico and Arizona. Based on multiple statistical criteria (coefficient of determination, index of agreement, Nash-Sutcliffe efficiency) and ease of measurement in the forest, we identified DBH as the primary independent variable for estimating SA across all sites. Based on group regression analysis, we found allometric relationships to be significantly $(p<0.05)$ different for the same species (ponderosa pine, Douglas-fir) across different sites. Overall, our allometric relationships provide a valuable database for estimating transpiration at different spatial scales from sap flow data in some of our most vulnerable ecosystems.

Keywords Allometry - Diameter at breast height . Mountain ecosystem $\cdot$ Sapwood area $\cdot$ Southwestern USA

$\begin{array}{ll}\text { Abbreviations } & \\ \text { MAPE } & \text { Absolute percentage error } \\ \text { AIC } & \text { Akaike information criterion, } \\ R^{2} & \text { Coefficient of determination } \\ \text { CZO } & \text { Critical Zone Observatory } \\ C D(\mathrm{~m}) & \text { Canopy diameter } \\ D B H(\mathrm{~cm}) & \text { Diameter at breast height } \\ \text { IOA } & \text { Index of agreement } \\ \text { JRB } & \text { Jemez River Basin } \\ \text { ZOB } & \text { Zero-Order Basin } \\ \text { JRB SE ZOB } & \text { Jemez River Basin South-East Zero Order } \\ & \text { Basin }\end{array}$




$\begin{array}{ll}\text { JRB SW ZOB } & \text { Jemez River Basin South-West Zero } \\ & \text { Order Basin } \\ \text { LiDAR } & \text { Light detection and range } \\ \text { MAT }\left({ }^{\circ} \mathrm{C}\right) & \text { Mean annual temperature } \\ \text { MAP }(\mathrm{mm}) & \text { Mean annual precipitation } \\ \text { NSE } & \text { Nash-Sutcliffe efficiency } \\ \text { NAM } & \text { North American summer monsoon } \\ \text { SA }\left(\mathrm{cm}^{2}\right) & \text { Sapwood area } \\ \text { SE } & \text { Standard error } \\ \text { SEE } & \text { Standard error of estimate } \\ H(\mathrm{~m}) & \text { Tree height } \\ \text { VCNP } & \text { Valles Caldera National Preserve }\end{array}$

\section{Introduction}

High-elevation, snow-dependent, semiarid forest ecosystems across the southwestern United States are vulnerable to climate change (Williams et al. 2010; Allen et al. 2015), with significant implications for the associated coupled human-natural systems (Seager et al. 2007). These include changes in the hydrologic inputs to these ecosystems including alteration in the timing of the peak streamflow runoff and changes in precipitation frequency and magnitude (Barnett et al. 2005). However, by comparison, in part because of the difficulty in obtaining evapotranspiration estimates at the landscape scale across mountainous terrains (Reba et al. 2009), much less is known about the impact of climate change on this important water flux.

Transpiration is the dominant component of evapotranspiration compared to soil evaporation across high elevation ecosystem (Wilson et al. 2001). The water-use of individual trees, referred to as sap flux or sap flux density is commonly measured using sap flow techniques (Granier 1987; Clearwater et al. 1999). Sap flux density is multiplied by the sapwood area (SA) of the cross section of a trunk to obtain treelevel transpiration and multiplied by the sap wood area index (sapwood area/ground area) or by leaf area index (leaf area/ ground area) to quantify transpiration per square meter of ground area (Vertessy et al. 1997; Bovard et al. 2005; Herbst et al. 2007; Kumagai et al. 2007; Loranty et al. 2008; Mackay et al. 2010). Scaling of sap flux density to the canopy and landscape level to quantify transpiration is crucial for addressing critical questions not only with regard to impact of climate change but also with regard to "forest water use and potential water conservation on ecosystem-scale processes" (Warren et al. 2011).

Therefore, a reliable estimation of SA has remained a key component when quantifying transpiration at various spatial scales (tree, stand) (Wullschleger et al. 2001). SA is quantified by establishing allometric relationships between sapwood depth of a representative subset of trees and more easily measured stand parameters such as diameter at breast height (DBH) (or other substituting factors) using a representative sample of trees (Vertessy et al. 1995; Cienciala et al. 2000; Roberts et al. 2001; Wullschleger et al. 2001). Allometric relationships can enable the use of measurements from those trees to represent the greater ecosystem.

SA within a tree has been known to vary as a function of species (Kaufmann and Troendle 1981) and site conditions (Xie et al. 2012), even though some researchers have found these relationships to be independent of the aforementioned factors (e.g., Pastor et al. 1984; Bartelink 1996, 1997). Analysis of individual tree water-use across the high elevation ecosystem of the Southwest United States have found pronounced interspecies variability in sap velocity, necessitating the need to establish species-specific allometric relationships for the dominant vegetation across these sites (Small and McConnell 2008; Mitra and Papuga 2012).

To the best of our understanding, data on species-specific allometric relationship of the dominant vegetation across these sites remain scarce (McDowell et al. 2002). DBH remains the main scaling parameter for quantifying SA. We were motivated to analyze whether other independent structural properties such as canopy diameter (CD) or tree height $(H)$ can be used to predict SA. These variables have been less frequently used, and we are not aware of any studies that have revealed an allometric relationship between SA and $\mathrm{CD}$ (or $H$ ) for vegetation across Arizona and New Mexico.

These relationships may prove valuable for future research that requires scaling sap flux density to multiple spatial (tree/stand) resolution. The primary objective of this study was therefore to present allometric relationships linking SA to primary size measures (DBH, $\mathrm{CD}, H$ ) of common conifer and deciduous species across the high-elevation system in the Southwest United States.

\section{Materials and methods}

\section{Study area}

Our study sites are located in the semiarid high elevation mixed-forest ecosystems of southern Arizona and northern New Mexico (Fig. S1). In northern New Mexico, the site is located in the Valles Caldera National Preserve (VCNP), west of Los Alamos, New Mexico. In southern Arizona, the site is located in the Santa Catalina Mountains (SCM) of the Coronado National Forest, northeast of Tucson, Arizona. Our study sites are part of the University of Arizona (UA) Santa Catalina Mountain-Jemez River Basin Critical Zone Observatory (UA SCM-JRB CZO; www.czo.arizona.edu) (Fig. S1).

Mean elevation at VCNP is $2768 \mathrm{~m}$ a.s.l. (range 2167-3434 m) and mean slope of the relief is $12.8^{\circ}$ (maximum $75.4^{\circ}$ ) (U.S. Geological Survey 2003; Veatch et al. 
Table 1 Mean $( \pm \mathrm{SE})$ of diameter at breast height $(\mathrm{DBH})$, canopy diameter $(\mathrm{CD})$ and tree height $(H)$ of the dominant conifer and deciduous species that were surveyed in New Mexico (NM) and Arizona (AZ), United States

\begin{tabular}{|c|c|c|c|c|c|c|c|}
\hline Location & Site & Common name & Species & $\mathrm{N}$ & $\mathrm{DBH}, \mathrm{cm}( \pm \mathrm{SE})$ & $\mathrm{CD}, \mathrm{cm}( \pm \mathrm{SE})$ & $H, \mathrm{~cm}( \pm \mathrm{SE})$ \\
\hline \multirow[t]{7}{*}{ NM } & US-Vcm & Engelmann spruce & Picea engelmannii & 73 & $20.7(1.03)$ & $2.6(0.1)$ & $11.2(0.5)$ \\
\hline & US-Vcp & Ponderosa pine & Pinus ponderosa & 57 & $34.9(2.07)$ & $3.7(0.13)$ & $15.6(0.33)$ \\
\hline & JRB SW ZOB & Douglas-fir & Pseudotsuga menziesii & 12 & $28.79(1.97)$ & $3.51(0.30)$ & NA \\
\hline & & Engelmann spruce & Picea engelmannii & 8 & $35.12(2.48)$ & $4.76(0.26)$ & $15.90(1.15)$ \\
\hline & JRB SE ZOB & Douglas-fir & Pseudotsuga menziesii & 8 & $15.06(3.19)$ & $2.87(0.39)$ & NA \\
\hline & & Engelmann spruce & Picea engelmannii & 11 & $32.26(2.54)$ & $5(0.28)$ & $15.65(1.01)$ \\
\hline & & Quaking aspen & Populus tremuloides & 10 & $47.89(3.7)$ & $5.98(0.61)$ & $18.96(0.99)$ \\
\hline \multirow[t]{6}{*}{$\mathrm{AZ}$} & Schist ZOB & Douglas-fir & Pseudotsuga menziesii & 10 & $55.98(9.978)$ & NA & NA \\
\hline & & White fir & Abies concolor & 13 & $55.78(5.6)$ & $5.71(0.54)$ & $21.66(4.17)$ \\
\hline & & Maple & Acer grandidentatum & 12 & $21.94(1.37)$ & NA & NA \\
\hline & Granite ZOB & Douglas-fir & Pseudotsuga menziesii & 14 & $47.47(6.36$ & $5.44(0.59$ & $22.22(2.55)$ \\
\hline & & White fir & Abies concolor & 14 & $31.65(3.70)$ & $4.64(0.22)$ & $15.91(1.42)$ \\
\hline & Oracle Ridge ZOB & Ponderosa pine & Pinus ponderosa & 20 & $56.85(2.40$ & NA & NA \\
\hline
\end{tabular}

NA, insufficient data

2009). The climate is semiarid continental with a mean annual temperature (MAT) between 6 and $10{ }^{\circ} \mathrm{C}$ (Table S1). Mean annual precipitation (MAP) is bimodal and is influenced by both the North American summer monsoon (NAM) as well as winter storms that originate from the Pacific Ocean. Approximately $65 \%$ of MAP falls in the form of snow between October and April and the remaining 35\% as rain between July and September (Molotch et al. 2009).

MAP in the upper elevations of the SCM is $\sim 820 \mathrm{~mm} \mathrm{a}^{-1}$ (Brown-Mitic et al. 2007; Table S1). Nearly 25\% of that precipitation originates from the NAM, while the remainder falls in the form of snow and rain between December and March (Brown-Mitic et al. 2007). Except during the monsoon season, the SCM remains dry throughout the rest of the year with the average relative humidity typically below $30 \%$ (Gochis et al. 2006).

Two sites at VCNP are located within Jemez River watershed and are dominated by Engelmann spruce (Picea engelmannii) and ponderosa pine (Pinus ponderosa) (Brooks and Vivoni 2008; McDowell et al. 2008). These two sites will henceforth be referred to by their Ameriflux Site Codes as US-Vcm (coordinates: 35.88, - 106.54) and US-Vcp (coordinates: $35.86,-106.59$ ) respectively.

The third VCNP site, less than $3.21 \mathrm{~km}$ from the MC Tower site and at a similar elevation, is part of the Jemez River Basin High-Elevation Zero Order Basin (JRB ZOB). Vegetation within the JRB ZOB is dominated by mixed conifer and spruce-fir forest, quaking aspen (Populus tremuloides) as well as grassland.

Our two high-elevation study sites at SCM are located in Marshall Gulch, a $1.54 \mathrm{~km}^{2}$ catchment within the Upper Sabino Canyon watershed (coordinates: 32.43, - 110.77) (Lyon and Troch 2010). These two sites, granite zero order basin (granite ZOB, 5.6 ha) and schist zero-order basin (schist ZOB, 4.9 ha) have similar weather, shape and slope (Table S1). Dominant vegetation within both the catchment include Douglas-fir (Pseudotsuga menziesii), white fir (Abies concolor), ponderosa pine ( $P$. ponderosa) and big-toothed maple (Acer grandidentatum) (Jardine 2011).

Our third field site in the SCM is the Oracle Ridge ZOB (coordinates: $32.58,-110.76)$. The elevation varies between 2000 and $2300 \mathrm{~m}$ a.s.1., with the dominant vegetation at this site being ponderosa pine. Descriptive statistics of the dominant vegetation across all the sites that were surveyed to estimate are summarized in Table 1.

\section{Field measurements}

A single $30 \mathrm{~m} \times 30 \mathrm{~m}$ plot was established at the JRB SE and JRB SW ZOBs, and a $60 \mathrm{~m} \times 60 \mathrm{~m}$ plot size was established at the schist and granite ZOBs. The difference in plot size was to account for the higher stand density at JRB SE and JRB SW ZOBs and the sparse vegetation at the schist and granite ZOBs. At the US-Vcm and US-Vcp sites, we constructed variable-radius plots (Babst et al. 2014). All trees with DBH greater than $6 \mathrm{~cm}$ were surveyed in each plot.

Within each plot, we measured DBH (1.37 m above ground), $H$ and $\mathrm{CD}$ of each tree. $\mathrm{CD}$ was the average crown spread of the shortest and longest measurement from one edge of the crown to the other. $H$ was measured with an electronic laser range finder (NIKON Forestry Pro Laser Rangefinder/Hypsometer). Within each plot, increment cores were collected at breast height with a 5-mm-diameter borer to estimate sap wood area. Two perpendicular cores were collected to account for eccentricities in growth around the circumference. The portion between the heartwood and bark 
was identified to be the sapwood depth. For all the samples, the boundary between heartwood and sapwood was based on the darker color of the heartwood. This visual inspection was consistent with the method established by other researchers (Hatton et al. 1995; Vertessy et al. 1995; McDowell et al. 2008). SA was calculated as the difference between total xylem area and the heartwood area, and wherever two cores were collected, mean of the two radii represents the total SA of the tree.

\section{Allometry}

The species-specific allometric relation between SA and the three size measures DBH, CD, or $H$ was modeled using a power law (Causton 1985; Sanaei et al. 2019):

$A_{\mathrm{s}}=\beta x^{\alpha}$

where $\alpha$ is the scaling exponent, $\beta$ is a normalization constant, $x$ is the primary size measure (DBH, CD, $H$ ), and $A_{\mathrm{s}}$ is SA. The natural $\log (\mathrm{ln})$ transformation can be expressed in a linear form as follows:

$\ln A_{s}=\alpha \ln x+\ln \beta$,

Equations 1 and 2, mathematically equivalent, are different statistically, thereby necessitating the need to apply a back-correction factor to correct bias in logarithmic regression estimates (Ali et al. 2015; Paul et al. 2016). The backcorrection factor (CF) was calculated as follows (Sprugel 1983):

$\mathrm{CF}=\exp \left(\frac{\mathrm{SEE}^{2}}{2}\right)$.

The final equation will have the following form:

$\operatorname{Ln} A_{\mathrm{s}}=\mathrm{CF}(\alpha \ln x+\ln \beta \pm \epsilon)$.

We used a group regression procedure to determine whether model deviance changed significantly when we generalized the regression coefficients ( $\alpha$ and $\beta$ ) for the same vegetation across different sites.

Statistical summary includes errors (SE) and standard error of estimates (SEE). The primary model selection criteria was coefficient of determination $\left(R^{2}\right)$. However, to get a better sense of the deviation between measured and predicted values, we also measured mean absolute percentage error (MAPE), Nash-Sutcliffe efficiency (NSE) (Nash and Sutcliffe 1970) and index of agreement (IOA) (Willmott 1981). The Akaike information criterion (AIC) was calculated to get an understanding of the trade-off between model fit and model complexity. Heteroskedasticity for the best model fit (Eqs. 1 or 4) was analyzed visually by plotting the residuals (model-measured SA) against the best explanatory variable (SA, DBH, $H$ ). All statistical analysis were conducted in R (version 3.3.2, R Core Team 2016).

\section{Result}

In New Mexico (NM), DBH, CD and $H$ of ponderosa pine at US-Vcp were all greater than for spruce at the US-Vcm (Table 1). Of all the vegetation surveyed at JRB, aspen had the highest DBH, CD and $H$ (Table 1). In Arizona (AZ), there was no significant difference between the DBH of Douglas-fir obtained at the schist and granite ZOBs $(p<0.05)$. Maple at schist ZOB and ponderosa pine at Oracle Ridge had the smallest and largest DBH of all the species that were surveyed in Arizona.

In the case of spruce collected in NM, DBH was positively correlated $(p<0.05)$ with SA with both the power (Exp, Eq. 1, Fig. 1a, Table 2) and log (Eq. 4, Table S2) functions accounting for more than $90 \%$ of the variation. NSE and IOA values for both the model fits (power, $\log$ ) were close to unity (Table 2, Table S2). The overall model accuracy error, as measured by MAPE was lower when the log format was used (Table 2, Table S2). Unlike DBH, $R^{2}$ and NSE and IOA values were much lower when $H$ (or CD) was

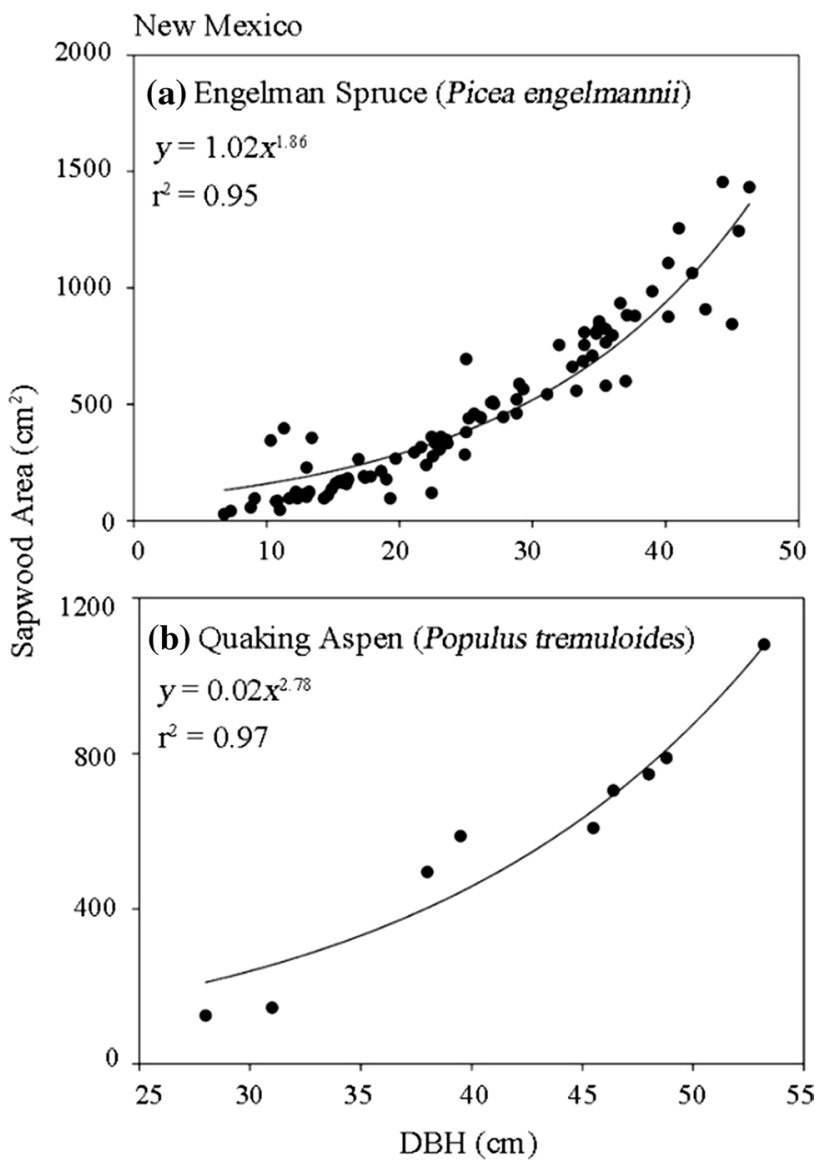

Fig. 1 Relationship between sapwood area (SA) and diameter at breast height (DBH) for Engelmann spruce (Picea engelmannii) (a) and quaking aspen (Populus tremuloides) (b). Detailed summary statistics of the model fits are in Table 2 
Table 2 Parameters and fit statistics for the relationship between sapwood area $\left(\mathrm{SA}, \mathrm{cm}^{2}\right.$,) and diameter at breast height (DBH, $\left.\mathrm{cm}\right)$ for different species in New Mexico (NM) and Arizona (AZ), United States

\begin{tabular}{|c|c|c|c|c|c|c|c|c|c|c|}
\hline Species & Site & Parameter & $\alpha(\mathrm{SE})$ & $\beta(\mathrm{SE})$ & SEE & MAPE & $R^{2}$ & NSE & IOA & AIC \\
\hline Picea engelmannii & NM & $\mathrm{DBH}$ & $1.86(0.08)$ & $1.02(0.29)$ & 103.22 & 18.05 & 0.95 & 0.95 & 0.97 & 1154.6 \\
\hline Populus tremuloides & NM & $\mathrm{DBH}$ & $2.78(0.35)$ & $0.02(0.02)$ & 78.68 & 18.38 & 0.97 & 0.94 & 0.98 & 107.85 \\
\hline \multirow[t]{2}{*}{ Pseudotsuga menziesii } & NM & $\mathrm{DBH}$ & $1.73(0.23)$ & $1.64(1.34)$ & 124.82 & 23.08 & 0.91 & 0.83 & 0.95 & 253.73 \\
\hline & $\mathrm{AZ}$ & $\mathrm{DBH}$ & $1.57(0.27)$ & $1.81(2.11)$ & 303.09 & 74.27 & 0.89 & 0.79 & 0.94 & 303.48 \\
\hline \multirow[t]{2}{*}{ Pinus ponderosa } & NM & $\mathrm{DBH}$ & $2.08(0.11)$ & $0.36(0.13)$ & 39.27 & 12.71 & 0.95 & 0.91 & 0.97 & 563.82 \\
\hline & $\mathrm{AZ}$ & DBH & $1.89(0.32)$ & $0.61(0.81)$ & 364.33 & 36.82 & 0.83 & 0.68 & 0.89 & 325.85 \\
\hline Acer gradidentatum & $\mathrm{AZ}$ & $\mathrm{DBH}$ & $2.3(0.41)$ & $0.37(0.49)$ & 98.86 & 19.34 & 0.93 & 0.86 & 0.96 & 111.97 \\
\hline Abies concolor & $\mathrm{AZ}$ & DBH & $1.62(0.17)$ & $1.43(1.06)$ & 250.89 & 26.39 & 0.93 & 0.87 & 0.96 & 392.78 \\
\hline
\end{tabular}

$\alpha$ and $\beta$, model parameters; SE, standard error; SEE, SE of estimate; $R^{2}$, adjusted coefficient of determination; MAPE, mean absolute percentage error; NSE is Nash-Sutcliffe efficiency; IOA, index of agreement; AIC, Akaike information criterion

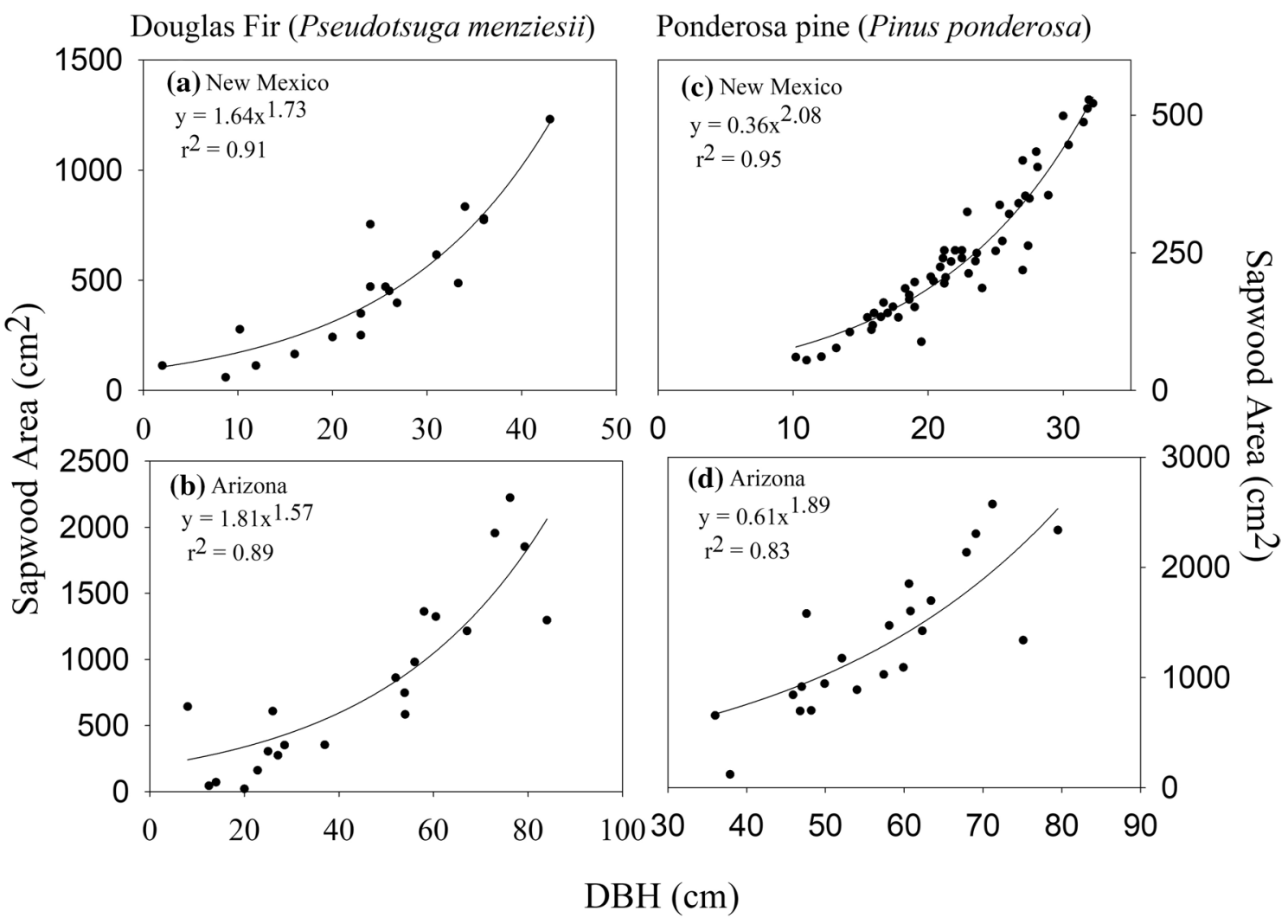

Fig. 2 Relationship between sapwood area (SA) and diameter at breast height (DBH) for Douglas fir (Pseudotsuga menziesii) (a, b) and ponderosa pine (Pinus ponderosa) (c, d). Detailed summary statistics of the model fits are in Table 2

regressed against SA (Table S2). Spruce samples collected from US-Vcm, JRB SW ZOB and JRB SE ZOB sites were pooled together for this analysis.

All estimators $\left(R^{2}, \mathrm{NSE}\right.$ and IOA) also established DBH as a strong independent variable to estimate SA for aspen at the New Mexico sites (Fig. 1b, Table 2). For Douglas-fir in New Mexico, the strength of correlation between SA and DBH was strong when the power (Fig. 2a, Table 2) function was used in comparison to the log function (Table S2). Correlation between $\mathrm{SA}$ and $\mathrm{CD}$ was equally strong, irrespective of the fact whether the power or natural log function was used (Table S2). Douglas-fir in New Mexico consisted of samples collected from both JRB SW ZOB and JRB SE ZOB sites. Similarly, the power function (Eq. 1) provided a strong fit between SA and DBH for Douglas fir samples collected from Arizona (Fig. 2b, Table S3). 


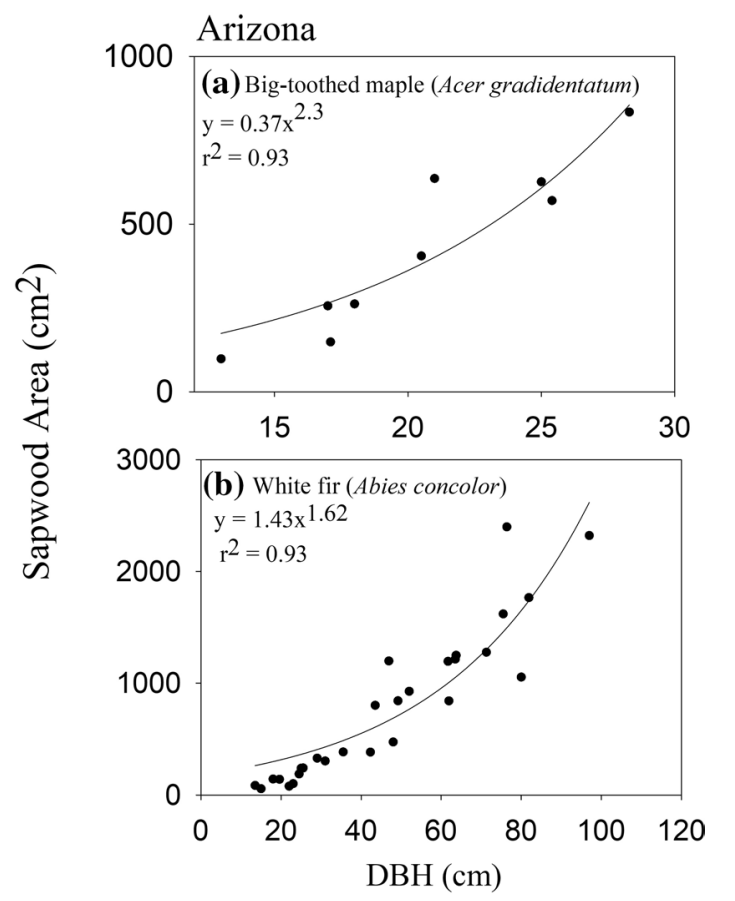

Fig. 3 Relationship between sapwood area (SA) and diameter at breast height (DBH) for big-toothed maple (Acer grandidentatum) (a) and white fir (Abies concolor) (b). Detailed summary statistics of the model fits are in Table 2

DBH accounted for more than $90 \%$ of the variation in SA using both the power (Eq. 1) and $\log (\mathrm{Eq} 4)$ functions for ponderosa pine in New Mexico (Fig. 2c, Table 2, Table S2). The strength of the correlation was slightly weaker in Arizona for the same species for both model fits (Fig. 2d, Table 2, Table S3). CD and $H$ were, however, weakly correlated with SA of ponderosa pine at US-Vcp (Table S2). We did not collect data for $\mathrm{CD}$ and $H$ for ponderosa pine at Oracle Ridge.

DBH was the best estimator of SA for maple at Arizona, with both power (Table 2) and log functions (Table S3) providing similar coefficient of determination (Fig. 3a). We did not have sufficient data to analyze the relation of $\mathrm{CD}$ and $H$ of maple with SA. In case of white fir at Arizona, both DBH (Eqs. 1, 4) and CD (Eq. 2) were strongly correlated with SA (Fig. 3b, Table 2, Table S3). We did not find any strong association between $H$ and SA for white fir (Table S3). White fir consisted of data collected from both schist and granite ZOBs.

Group regression analysis did not highlight significant impact $(p>0.05)$ of site conditions in modulating the allometric relationship between SA and DBH (or CD and $\mathrm{H}$ ) for Douglas-fir (and white fir) at the Schist and Granite ZOBs (when analyzed separately). This result was also true at MC ZOB, where conditions at US-V $\mathrm{cm}$, JRB SW ZOB and JRB SE ZOB sites were not a significant factor $(p>0.05)$ in influencing the allometric relationship for Douglas-fir and spruce (based on group regression analysis). Hence, the data for the same vegetation across these sites were pooled together to analyze the relationship between SA, DBH, CD and $H$. However, based on group regression analysis, $\alpha$ and $\beta$ for both Douglas-fir (Fig. 2a, b) and ponderosa pine (Fig. 2c, d) across New Mexico and Arizona were significantly different $(p<0.05)$.

\section{Discussion}

For quantifying the relationship between the active fluidtransporting surface area of common southwestern conifer and deciduous tree species against easily measured stand variables such as DBH, $H$ or $\mathrm{CD}$ in high-elevation, snowdependent, semiarid ecosystems of the Southwest United States, we analyzed conifer and deciduous species separately because of their major differences in biomass, growth strategy, water transport pattern and abiotic stress responses (Dunisch and Morais 2002; Bovard et al. 2005; Mitra and Papuga 2012). They also have very different wood anatomy and, therefore, different specific conductivity. For example, the tracheids within coniferous species can conduct water, whereas only vessels within nonconductive fiber cells conduct water in angiosperm species.

We analyzed the model fits using multiple objective mathematical indicators ( $R^{2}$, MAE, IOA, NSE) because data transformation can distort our understanding of the "closeness" between measured and modelled data (Krause et al. 2005). Ideally, an ideal model fit will have high $R^{2}$ values, NSE and IOA values close to 1 . The MAPE values, however, differed between the two model fits (Table 2; Tables S2, S3). However, we did not use these values as a criterion, primarily because they can in general be biased toward poorly predicting models (Toffalis 2015). A complete summary of the advantage and disadvantages of using MAPE as a selection criterion for model fit has been extensively documented (Hyndman and Koehler 2006; Kim and Kim 2016). Similarly, as the number of candidate models was only two (power and log, Eqs. 1, 4) with only two parameters, we did not use AIC as a criterion to select the optimum model fit.

DBH remains a well-established variable for tree allometry analysis (Landsberg and Gower 1997; TerMikaelian and Korzukhin 1997). Our attempt to quantify the relationship between SA and CD (or $H$ ) was primarily driven by the motivation to identify other independent variables that can be used to model SA. To that end, CD (e.g., white fir in Arizona and Douglas fir in New Mexico) was strongly correlated with SA.

However, apart from statistical performance, application in the field was a significant factor in our choice of the best model fit (Niklas 1994). Hence, we have selected DBH (Eq. 1) as the primary independent variable because 
DBH can be measured with more precision than CD or $H$ in the forest (Bond-Lamberty et al. 2002). The high degree of correlation between SA and DBH for all the species surveyed was consistent with general allometric theory (Cermak et al. 1992; Vertessy et al. 1995; Wullschleger and King 2000; Gebauer et al. 2008; Matyssek et al. 2009; Kume et al. 2010). We presented the results as both power (Eq. 1) and $\log$ functions (Eq. 4) to facilitate comparison of our results with other published data for similar vegetation and from different ecosystems. Except for Douglas fir in NM, there were no major differences (based on $R^{2}$ ) between the two model formats in predicting SA from DBH (Table 2, Tables S2, S3). Residual plots for SA versus DBH (Eq. 1) did not detect any non-random pattern for any of the species that we surveyed in New Mexico and Arizona (Fig. S2).

We do not believe our approach in estimating the wet-dry transition in tree cores overestimated SA. Bush et al. (2010) showed that the use of dyes on tree cores highlighted significant differences in the heartwood and sapwood transition only for ring-porous species. In our study, we sampled conifer species and diffuse-porous angiosperms and found no significant differences between our approaches of sapwood area estimation versus the use of dyes. We note that a critical factor not addressed by our study is the impact of stand age in modulating the allometric relationships. Multiple factors change with stand age, including soil and management conditions, presenting even more of a challenge. Still, our data set provides a much-needed step forward for calculating water balance in vulnerable semi-arid ecosystems.

We were motivated to compare the SA-DBH allometry of ponderosa pine and Douglas fir across the JRB and SCM site to analyze the representativeness of the SA-DBH relationship for the same species across the southwestern mountain ecosystem of the United States. Based on group regression analysis, the parameter coefficients differed significantly for each species (Eqs. 1, 4) across the two sites. This result was not surprising and may have been influenced by multiple factors apart from elevation, including age of the tree and structure of the stand (Hernandez-Santana et al. 2015).

\section{Conclusions}

Our comprehensive assessment of the allometric relationship of the dominant vegetation across high-elevation, snowdependent, semiarid ecosystems in the southwestern United States (Arizona and New Mexico) is a valuable addition to the existing body of literature (McDowell et al. 2002). Establishment of species-specific allometric models will simplify estimation of evaporation, transpiration and carbon flux using tree height and canopy diameter measurements measured remotely by terrestrial and aerial light detection and range (LiDAR) (Zhao and Popescu 2007; Falkowski et al. 2008; Swetnam and Falk 2014). With the exception of high point density terrestrial laser scanning, diameter at breast height cannot be measured directly using relatively lowerdensity aerial LiDAR scanning collections. Having robust species-level models that predict individual tree SA and total fluid flux based on tree size are a critical part of accurately estimating landscape-scale evaporation and transpiration and predicting potential hydraulic failure and tree death (Farrior et al. 2013; Gentine et al. 2016).

A natural extension of this research will be incorporating this species-specific SA-DBH allometric data to estimate stand-level transpiration (Granier 1987; Meinzer et al. 2001; James et al. 2002; Ford et al. 2004; Oishi et al. 2008). The analysis of species contribution to total stand transpiration is an emergent topic (Gebre et al. 1998; Ewers et al. 2002; Kostner et al. 2002; Pataki et al. 2005; Hernandez-Santana et al. 2015; Venkatraman and Ashwath 2016). A recent study across Alaska and western Canadian boreal forests found significant differences among deciduous and conifer tree species in their capacity to take up snowmelt water (YoungRobertson et al. 2016). Such analysis remains strongly relevant across the Southwest United States considering the expected shift in vegetation composition across this region due to changes in the climate change and, consequently, the terrestrial water cycle (Swetnam and Betancourt 1998; Diffenbaugh et al. 2008; Schwinning et al. 2008; Brusca et al. 2013).

Acknowledgements A very special note of thanks to Dr. Valerie Trouet, Dr. David J. P. Moore, Emily Dynes, Ian Shiach, Dr. Julia N. Perdrial, Michael Pohlmann and Lori Lovell during the collection of tree core samples and the tree survey. M.R.A. was supported by the DOE Regional and Global Climate Modeling program DE-SC0016011 and by the University of Arizona Water, Environment, and Energy Solutions (WEES) and Sustainability of Semi-Arid Hydrology and Riparian Areas (SAHRA) programs.

Author contributions BM conceived the study, collected tree core samples, analyzed the data and wrote the manuscript. SP conceived the study and assisted in data analysis and writing the manuscript. TS provided feedback and assisted in writing the manuscript. MRA assisted in collection of tree core samples and provided feedback during the development of the manuscript. NA assisted in collection of tree core samples and provided feedback to improve the manuscript.

Open Access This article is distributed under the terms of the Creative Commons Attribution 4.0 International License (http://creativeco mmons.org/licenses/by/4.0/), which permits unrestricted use, distribution, and reproduction in any medium, provided you give appropriate credit to the original author(s) and the source, provide a link to the Creative Commons license, and indicate if changes were made. 


\section{References}

Ali A, Xu MS, Zhao YT, Zhang QQ, Zhou LL, Yang XD, Yan ER (2015) Allometric biomass equations for shrub and small tree species in subtropical China. Silva Fennica 49(4):1-10

Allen CD, Breshears DD, McDowell NG (2015) On underestimation of global vulnerability to tree mortality and forest die-off from hotter drought in the Anthropocene. Ecosphere 6(8):1-55. https ://doi.org/10.1890/es15-00203.1

Babst F, Alexander MR, Szejner P, Bouriaud O, Klesse S, Roden J, Ciais P, Poulter B, Frank D, Moore DJP, Trouet V (2014) A tree-ring perspective on the terrestrial carbon cycle. Oecologia 176(2):307-322. https://doi.org/10.1007/s00442-014-3031-6

Barnett TP, Adam JC, Lettenmaier DP (2005) Potential impacts of a warming climate on water availability in snow-dominated regions. Nature 438(7066):303-309. https://doi.org/10.1038/nature04141

Bartelink HH (1996) Allometric relationships on biomass and needle area of Douglas-fir. For Ecol Manag 86(1-3):193-203. https://doi. org/10.1016/S0378-1127(96)03783-8

Bartelink HH (1997) Allometric relationships for biomass and leaf area of beech (Fagus sylvatica L). Ann For Sci 54:39-50. https://doi. org/10.1051/forest:19970104

Bond-Lamberty B, Wang C, Gower ST (2002) Aboveground and belowground biomass and sapwood area allometric equations for six boreal tree species of northern Manitoba. Can J For Res 32:1441-1450

Bovard BD, Curtis PS, Vogel CS, Su HB, Schmid HP (2005) Environmental controls on sap flow in a northern hardwood forest. Tree Physiol 25(1):31-38

Brooks PD, Vivoni ER (2008) Mountain ecohydrology: quantifying the role of vegetation in the water balance of montane catchments. Ecohydrology 1(3):187-192. https://doi.org/10.1002/eco.27

Brown-Mitic C, Shuttleworth WJ, Harlow RC, Petti J, Burke E, Bales R (2007) Seasonal water dynamics of a sky island subalpine forest in semi-arid southwestern United States. J Arid Environ 69(2):237258. https://doi.org/10.1016/j.jaridenv.2006.09.005

Brusca RC, Wiens JF, Meyer WM, Eble J, Franklin K, Overpeck JT, Moore W (2013) Dramatic response to climate change in the Southwest: Robert Whittaker's 1963 Arizona Mountain plant transect revisited. Ecol Evolut 3(10):3307-3319. https://doi. org/10.1002/ece 3.720

Bush SE, Hultine KR, Sperry JS, Ehleringer JR (2010) Calibration of thermal dissipation sap flow probes for ring- and diffuse-porous trees. Tree Physiol 30(12):1545-1554. https://doi.org/10.1093/ treephys/tpq096

Causton DR (1985) Biometrical, structural and physiological relationships among tree parts. In: Cannell MGR, Jackson JE (eds) Attributes of trees as crop plants. Institute of Terrestrial Ecology, Monks Wood, Huntingdon, pp 137-159

Cermak J, Cienciala E, Kucera J, Hallgren JE (1992) Radial-velocity profiles of water-flow in trunks of norway spruce and oak and the response of spruce to severing. Tree Physiol 10(4):367-380

Cienciala E, Kucera J, Malmer A (2000) Tree sap flow and stand transpiration of two Acacia mangium plantations in Sabah, Borneo. J Hydrol 236(1-2):109-120. https://doi.org/10.1016/s0022 $-1694(00) 00291-2$

Clearwater MJ, Meinzer FC, Andrade JL, Goldstein G, Holbrook NM (1999) Potential errors in measurement of nonuniform sap flow using heat dissipation probes. Tree Physiol 19(10):681-687

Diffenbaugh NS, Giorgi F, Pal JS (2008) Climate change hotspots in the United States. Geophys Res Lett 35(16):L16709. https:// doi.org/10.1029/2008g1035075

Dunisch O, Morais RR (2002) Regulation of xylem sap flow in an evergreen, a semi-deciduous, and a deciduous Meliaceae species from the Amazon. Trees-Struct Funct 16(6):404-416. https://doi.org/10.1007/s00468.002.0182.6

Ewers BE, Mackay DS, Gower ST, Ahl DE, Burrows SN, Samanta SS (2002) Tree species effects on stand transpiration in northern Wisconsin. Water Resources Res. https://doi.org/10.1029/2001w r000830

Falkowski MJ, Smith AMS, Gessler PE, Hudak AT, Vierling LA, Evans JS (2008) The influence of conifer forest canopy cover on the accuracy of two individual tree measurement algorithms using lidar data. Can J Remote Sens 34:S338-S350

Farrior CE, Dybzinski R, Levin SA, Pacala SW (2013) Competition for water and light in closed-canopy forests: a tractable model of carbon allocation with implications for carbon sinks. Am Nat 181(3):314-330. https://doi.org/10.1086/669153

Ford CR, McGuire MA, Mitchell RJ, Teskey RO (2004) Assessing variation in the radial profile of sap flux density in Pinus species and its effect on daily water use. Tree Physiol 24(3):241-249

Gebauer T, Horna V, Leuschner C (2008) Variability in radial sap flux density patterns and sapwood area among seven cooccurring temperate broad-leaved tree species. Tree Physiol 28(12):1821-1830

Gebre GM, Tschaplinski TJ, Shirshac TL (1998) Water relations of several hardwood species in response to throughfall manipulation in an upland oak forest during a wet year. Tree Physiol 18(5):299-305

Gentine P, Guerin M, Uriarte M, McDowell NG, Pockman WT (2016) An allometry-based model of the survival strategies of hydraulic failure and carbon starvation. Ecohydrology 9(3):529-546. https://doi.org/10.1002/eco.1654

Gochis DJ, Brito-Castillo L, Shuttleworth WJ (2006) Hydroclimatology of the North American Monsoon region in northwest Mexico. J Hydrol 316(1-4):53-70. https://doi.org/10.1016/j. jhydrol.2005.04.021

Granier A (1987) Evaluation of transpiration in a douglas-fir stand by means of sap flow measurements. Tree Physiol 3(4):309-319

Hatton TJ, Moore SJ, Reece PH (1995) Estimating stand transpiration in a Eucalyptus populnea woodland with the heat pulse method: measurement errors and sampling strategies. Tree Physiol 15(4):219-227

Herbst M, Roberts JM, Rosier PTW, Taylor ME, Gowing DJ (2007) Edge effects and forest water use: a field study in a mixed deciduous woodland. For Ecol Manag 250(3):176-186. https://doi. org/10.1016/j.foreco.2007.05.013

Hernandez-Santana V, Hernandez-Hernandez A, Vadeboncoeur MA, Asbjornsen H (2015) Scaling from single-point sap velocity measurements to stand transpiration in a multispecies deciduous forest: uncertainty sources, stand structure effect, and future scenarios. Can J For Res 45(11):1489-1497. https://doi. org/10.1139/cjfr-2015-0009

Hyndman RJ, Koehler AB (2006) Another look at measures of forecast accuracy. Int J Forecast 22(4):679-688. https://doi. org/10.1016/j.ijforecast.2006.03.001

James SA, Clearwater MJ, Meinzer FC, Goldstein G (2002) Heat dissipation sensors of variable length for the measurement of sap flow in trees with deep sapwood. Tree Physiol 22(4):277-283

Jardine AB (2011) Aqueous phase tracers of chemical weathering in a semi-arid mountain critical zone. The University of Arizona, Tucson

Kaufmann MR, Troendle CA (1981) The relationship of leaf-area and foliage biomass to sapwood conducting area in 4 subalpine forest tree species. For Sci 27(3):477-482

Kim S, Kim H (2016) A new metric of absolute percentage error for intermittent demand forecasts. Int J Forecast 32(3):669-679. https ://doi.org/10.1016/j.ijforecast.2015.12.003

Kostner B, Falge E, Tenhunen JD (2002) Age-related effects on leaf area/sapwood area relationships, canopy transpiration and carbon 
gain of Norway spruce stands (Picea abies) in the Fichtelgebirge, Germany. Tree Physiol 22(8):567-574

Krause P, Boyle DP, Bäse F (2005) Comparison of different efficiency criteria for hydrological model assessment. Can J For Res 32:1441-1450

Kumagai T, Aoki S, Shimizu T, Otsuki K (2007) Sap flow estimates of stand transpiration at two slope positions in a Japanese cedar forest watershed. Tree Physiol 27(2):161-168

Kume T, Tsuruta K, Komatsu H, Kumagai T, Higashi N, Shinohara Y, Otsuki K (2010) Effects of sample size on sap flux-based standscale transpiration estimates. Tree Physiol 30(1):129-138. https ://doi.org/10.1093/treephys/tpp074

Landsberg JJ, Gower ST (1997) Applications of physiological ecology to forest management. Academic, San Diego

Loranty MM, Mackay DS, Ewers BE, Adelman JD, Kruger EL (2008) Environmental drivers of spatial variation in whole-tree transpiration in an aspen-dominated upland-to-wetland forest gradient. Water Resources Res. https://doi.org/10.1029/2007wr006272

Lyon SW, Troch PA (2010) Development and application of a catchment similarity index for subsurface flow. Water Resour Res. https ://doi.org/10.1029/2009wr008500

Mackay DS, Ewers BE, Loranty MM, Kruger EL (2010) On the representativeness of plot size and location for scaling transpiration from trees to a stand. J Geophys Res Biogeosci. https://doi. org/10.1029/2009jg001092

Matyssek R, Wieser G, Patzner K, Blaschke H, Haberle KH (2009) Transpiration of forest trees and stands at different altitude: consistencies rather than contrasts? Eur J For Res 128(6):579-596. https://doi.org/10.1007/s10342-008-0243-5

McDowell N, Barnard H, Bond BJ, Hinckley T, Hubbard RM, Ishii H, Köstner B, Magnani F, Marshall J, Meinzer F, Phillips N, Ryan M, Whitehead D (2002) The relationship between tree height and leaf area: sapwood area ratio. Oecologia 132(1):12-20. https:// doi.org/10.1007/s00442-002-0904-x

McDowell NG, White S, Pockman WT (2008) Transpiration and stomatal conductance across a steep climate gradient in the southern Rocky Mountains. Ecohydrology 1(3):193-204. https://doi. org/10.1002/eco.20

Meinzer FC, Goldstein G, Andrade JL (2001) Regulation of water flux through tropical forest canopy trees: do universal rules apply? Tree Physiol 21(1):19-26

Mitra B, Papuga S (2012) Toward an improved understanding of the role of transpiration in critical zone dynamics. In: Fall Meeting AGU, San Francisco, Calif, 3-7 Dec Abstract H531-1650

Molotch NP, Brooks PD, Burns SP, Litvak M, Monson RK, McConnell JR, Musselman K (2009) Ecohydrological controls on snowmelt partitioning in mixed-conifer sub-alpine forests. Ecohydrology 2(2):129-142. https://doi.org/10.1002/eco.48

Nash JE, Sutcliffe JV (1970) River flow forecasting through conceptual model. Part 1-a discussion of principles. J Hydrol 10:282-290. https://doi.org/10.1016/0022-1694(70)90255-6

Niklas KJ (1994) Plant allometry: the scaling of form and process. University of Chicago Press, Chicago

Oishi AC, Oren R, Stoy PC (2008) Estimating components of forest evapotranspiration: a footprint approach for scaling sap flux measurements. Agric For Meteorol 148(11):1719-1732. https ://doi.org/10.1016/j.agrformet.2008.06.013

Pastor J, Aber JD, Melillo JM (1984) Biomass prediction using generalized allometric regressions for some northeast tree species. For Ecol Manag 7:265-274

Pataki DE, Bush SE, Gardner P, Solomon DK, Ehleringer JR (2005) Ecohydrology in a Colorado River riparian forest: implications for the decline of Populus fremontii. Ecol Appl 15(3):10091018. https://doi.org/10.1890/04-1272

Paul KI, Roxburgh SH, Chave J, England JR, Zerihun A, Specht A, Lewis T, Bennett LT, Baker TG, Adams MA, Huxtable D,
Montagu KD, Falster DS, Feller M, Sochacki S, Ritson P, Bastin G, Bartle J, Wildy D, Hobbs T, Larmour J, Waterworth R, Stewart HTL, Jonson J, Forrester DI, Applegate G, Mendham D, Bradford M, O'Grady A, Green D, Sudmeyer R, Rance SJ, Turner J, Barton C, Wenk EH, Grove T, Attiwill PA, Pinkard E, Butler D, Brooksbank K, Spencer B, Snowdon P, O'Brien N, Battaglia M, Cameron DM, Hamilton S, Mcauthur G, Sinclair J (2016) Testing the generality of above-ground biomass allometry across plant functional types at the continent scale. Glob Change Biol 22(6):2106-2124. https://doi.org/10.1111/ gcb. 13201

Reba ML, Link TE, Marks D, Pomeroy J (2009) An assessment of corrections for eddy covariance measured turbulent fluxes over snow in mountain environments. Water Resour Res. https://doi. org/10.1029/2008wr007045

Roberts S, Vertessy R, Grayson R (2001) Transpiration from Eucalyptus sieberi (L. Johnson) forests of different age. For Ecol Manag 143(1-3):153-161. https://doi.org/10.1016/s0378 $-1127(00) 00514-4$

Sanaei A, Ali A, Ahmadaali K, Jahantab E (2019) Generalized and species-specific prediction models for aboveground biomass in semi-steppe rangelands. J Plant Ecol 12(3):428-437. https://doi. org/10.1093/jpe/rty037

Schwinning S, Belnap J, Bowling DR, Ehleringer JR (2008) Sensitivity of the Colorado plateau to change: climate, ecosystems, and society. Ecol Soc 13:28

Seager R, Ting MF, Held I, Kushnir Y, Lu J, Vecchi G, Huang HP, Harnik N, Leetmaa A, Lau NC, Li C, Velez J, Naik N (2007) Model projections of an imminent transition to a more arid climate in southwestern North America. Science 316(5828):11811184. https://doi.org/10.1126/science.1139601

Small EE, McConnell JR (2008) Comparison of soil moisture and meteorological controls on pine and spruce transpiration. Ecohydrology 1(3):205-214. https://doi.org/10.1002/eco.25

Sprugel DG (1983) Correcting for bias in log-transformed allometric equations. Ecology 64(1):209-210. https://doi. org/10.2307/1937343

Swetnam TW, Betancourt JL (1998) Mesoscale disturbance and ecological response to decadal climatic variability in the American Southwest. J Clim 11(12):3128-3147. https://doi. org/10.1175/1520-0442(1998)011\%3c3128:mdaert\%3e2.0.co;2

Swetnam TL, Falk DA (2014) Application of Metabolic Scaling Theory to reduce error in local maxima tree segmentation from aerial LiDAR. For Ecol Manage 323:158-167. https://doi. org/10.1016/j.foreco.2014.03.016

TerMikaelian MT, Korzukhin MD (1997) Biomass equations for sixty-five North American tree species. For Ecol Manag 97(1):1-24. https://doi.org/10.1016/s0378-1127(97)00019-4

Veatch W, Brooks PD, Gustafson JR, Molotch NP (2009) Quantifying the effects of forest canopy cover on net snow accumulation at a continental, mid-latitude site. Ecohydrology 2(2):115-128. https://doi.org/10.1002/eco.45

Venkatraman K, Ashwath N (2016) Transpiration in 15 tree species grown on a phytocapped landfill site. Hydrol Curr Res 7:236. https://doi.org/10.4172/2157-7587.1000236

Vertessy RA, Benyon RG, Osullivan SK, Gribben PR (1995) Relationships between stem diameter, sapwood area, leaf-area and transpiration in a young mountain ash forest. Tree Physiol 15(9):559 567. https://doi.org/10.1093/treephys/15.9.559

Vertessy RA, Hatton TJ, Reece P, Osullivan SK, Benyon RG (1997) Estimating stand water use of large mountain ash trees and validation of the sap flow measurement technique. Tree Physiol 17(12):747-756

Warren JM, Potzelsberger E, Wullschleger SD, Thornton PE, Hasenauer H, Norby RJ (2011) Ecohydrologic impact of reduced 
stomatal conductance in forests exposed to elevated $\mathrm{CO}_{2}$. Ecohydrology 4(2):196-210. https://doi.org/10.1002/eco.173

Williams AP, Allen CD, Millar CI, Swetnam TW, Michaelsen J, Still CJ, Leavitt SW (2010) Forest responses to increasing aridity and warmth in the southwestern United States. Proc Natl Acad Sci USA 107(50):21289-21294. https://doi.org/10.1073/pnas.09142 11107

Willmott CJ (1981) On the validation of models. Phys Geogr 2(2):184194. https://doi.org/10.1080/02723646.1981.10642213

Wilson KB, Hanson PJ, Mulholland PJ, Baldocchi DD, Wullschleger SD (2001) A comparison of methods for determining forest evapotranspiration and its components: sap-flow, soil water budget, eddy covariance and catchment water balance. Agric For Meteorol 106(2):153-168. https://doi.org/10.1016/s0168-1923(00)00199-4

Wullschleger SD, King AW (2000) Radial variation in sap velocity as a function of stem diameter and sapwood thickness in yellow-poplar trees. Tree Physiol 20(8):511-518

Wullschleger SD, Hanson PJ, Todd DE (2001) Transpiration from a multi-species deciduous forest as estimated by xylem sap flow techniques. For Ecol Manag 143(1-3):205-213. https://doi. org/10.1016/s0378-1127(00)00518-1
Xie JB, Tang LS, Wang ZY, Xu GQ, Li Y (2012) Distinguishing the biomass allocation variance resulting from ontogenetic drift or acclimation to soil texture. PLoS ONE 7(7):e41502. https://doi. org/10.1371/journal.pone.0041502

Young-Robertson JM, Bolton WR, Bhatt US, Cristobal J, Thoman R (2016) Deciduous trees are a large and overlooked sink for snowmelt water in the boreal forest. Sci Rep. https://doi.org/10.1038/ srep29504

Zhao K, Popescu SC (2007) Hierarchical watershed segmentation of canopy height model for multi-scale forest inventory. In: Rönnholm P, Hyyppä H, Hyyppä J (eds) Proceedings of the ISPRS working group "Laser Scanning 2007 and SilviLaser 2007", ISPRS Volume XXXVI, Part3/W52. Espoo, September 12-14, 2007, Finland, pp 436-442

Publisher's Note Springer Nature remains neutral with regard to jurisdictional claims in published maps and institutional affiliations. 